\title{
Short Communication: Habitat and population characteristics of the endemic Java Tree Frog (Rhacophorus margaritifer) in Ranca Upas, West Java, Indonesia
}

\author{
TINA SAFARIA NILAWATI", HERNAWATI, REZA AHMAD TAUFIK ${ }^{\bullet \bullet}$ \\ Department of Biology Education, Faculty of Mathematics and Natural Sciences Education, Universitas Pendidikan Indonesia. J1. Dr. Setiabudhi No. 229 \\ Bandung 40154, West Java, Indonesia. Tel./fax: +62-22-2001108. `email: nilawati.ts@gmail.com, ${ }^{\bullet \bullet}$ hernawati_hidayat@yahoo.com
}

Manuscript received: 21 September 2018. Revision accepted: 20 May 2019.

\begin{abstract}
Nilawati TS, Hernawati, Taufik RA. 2019. Short Communication: Habitat and population characteristics of the endemic Java Tree Frog (Rhacophorus margaritifer) in Ranca Upas, West Java, Indonesia. Biodiversitas 20: 1644-1649. The Java tree frog (Rhacophorus margaritifer) is one of the endemic frogs of Indonesia. Ranca Upas forest, West Java, Indonesia is one of the habitats of this species which is threatened by the extension of the campground and tourism area. The aim of this study was to identify the habitat and population characteristics of Rhacophorus margaritifer in Ranca Upas forest. Data was collected through Capture-Mark-ReleaseRecapture method in every $100 \mathrm{~m}$ distance of a $300 \mathrm{~m}$ transect, along the river. The captured frogs were tagged using modified shoelaces. Habitat characteristics were analyzed descriptively and quantitatively, population number was estimated by the Schnabel method, and population distribution was calculated using the Morisita distribution index. The results showed that $R$. margaritifer habitat was at an altitude of $1630-1670 \mathrm{~m}$ asl with $16.6^{\circ} \mathrm{C}$ average air temperature and $90.8 \%$ air humidity. The habitat was near river with clear water and mud substrate at $14.8{ }^{\circ} \mathrm{C}$ water temperature, $0.068 \mathrm{~m} / \mathrm{s}$ water velocity, and neutral acidity. Furthermore, three species of plants, namely Strobilanthes crispus, Curculigo capitulata, and Cyathea sp. were identified to be very often used by $R$. margaritifer. Population abundance of $R$. margaritifer was estimated to be 286 individuals, with 5 individuals $/ 100 \mathrm{~m}^{2}$ density and it showed a clumped disp.ersion. Average size of frogs found in the study area was $40 \mathrm{~mm}$ Snout to Vent Length (SVL) and the range was 36 to 65 $\mathrm{mm}$. This showed that the location is dominated by young frogs and the study area is a good habitat for R. margaritifer.
\end{abstract}

Keywords: Anura, habitat, population, Ranca Upas, Rhacophorus margaritifer

\section{INTRODUCTION}

Indonesia is second in the global list of megabiodiversity countries of the world, after Brazil. It has a very strategic geographical position with many habitat types, each of which has a unique composition and richness of flora and fauna, including endemic plants and animals (Mittermeier et al. 1997). The country has been reported to have 816 species of endemic animals, including 259 species of mammals, 384 species of birds, and 173 amphibian species (IUCN 2013).

The existence of these endemic animals is very important because their extinction from Indonesia leads to total disappearance of them from the whole world. Indonesia is also known as a country with good number of wildlife species which have become endangered due to reduced habitat, hunting, and trade. The reduction in forest area is an important factor causing the extinction of wildlife because forests are their major habitat (Alikodra 2002). It was recorded that almost 84\% (around 162 million ha) of Indonesia's land was forest in the 1950's, which has been reduced over the years due to industrial and mining interests. Another recent report showed the forest area in the country is less than 120 million hectares (Ministry of Forestry 2012). Changes in habitat can threaten the existence of wildlife and when compared with other terrestrial animals, amphibians are more susceptible to the habitat damage due to their limited mobility (Gibbs, 1998; Bowne and Bowers 2004), low tolerance to extreme environments (Semlitsch 2000), easy exposure to pathogens, competition or predation, and pollution (Bridge and Semlitsch 2000; Stuart et al. 2004). An example for country's endemic amphibian species the existence of which has been threatened by the indiscriminate habitat modifications is Rhacophorus margaritifer, commonly called 'the Java tree frog'.

Rhacophorus margaritifer is a belong to the family Rhacophoridae and sub-family Rhacophorinae. The tree frog has characteristics distinguishing it from another genus of Rhacophoridae family. Rhacophorus margaritifer has relatively brighter body color, varying from brown to gray, with ring folds at the bottom of its disc. The size of the tympanum is $2 / 5$ th of the eye diameter and a skin fold above it (Van Kampen 1923). Furthermore, this frog has a body size of 50-60 $\mathrm{mm}$ and there are skin protrusions along the edge of its arm and the base of its foot to the outer finger. In 2004, IUCN declared $R$. margaritifer as a vulnerable species and due to increasing reports by researchers, its status was lowered to a low-risk category called 'Least concern' in 2009 (IUCN 2009).

Rhacophorus margaritifer is mostly found in the island of West, Central and East Java in primary and secondary forests at altitudes above 250-1500 m asl. (Iskandar 1998), 1000 meters above sea level (Frost 2018), and occupy areas 
with average daily temperature range of $16-17^{\circ} \mathrm{C}$ (Lubis 2008). Based on the altitude and average daily temperature, it can be concluded that the $R$. margaritifer habitat is a plateau. One of the highland areas with the above characteristics is the Ranca Upas area, Ciwidey, West Java.

There is a need to know the population and habitat of $R$. margaritifer, to support the preservation of this endemic frog species as there are no previous studies conducted on the subject. Therefore, this research was conducted to understand the habitat and population of $R$. margaritifer in the Ranca Upas area.

\section{MATERIALS AND METHODS}

\section{Study area}

This research was conducted between March and May 2018 in the heterogeneous forest area of Ranca Upas which is a campsite and protected forest location managed by PT. Perhutani III. This area is located in Patengan Village, Ciwidey Sub-district, Bandung District, West Java, Indonesia. It has an area of about 215 hectares with a protected forest area of 21.18 hectares consisting of primary, secondary, production forest and plantations (Figure 1) (Department of Tourism and Culture of West Java 2017).

\section{Catching and tagging of the frogs}

Rhacophorus margaritifer was caught 9 times manually by 3 people between 19.00-23.00 West Indonesian Time. After which the length of the mouth to the cloaca or snout to vent length (SVL) was measured using a caliper. This was followed by tagging using shoe threads tied to the frog's waist as shown in Figure 2 (Anggoro 2013). This method is new and has several advantages over other markings such as "toe clipping" (Hero, 1989) as it does not impair the movement of tree frogs, affordable and temporary (Anggoro 2013). After tagging, the $R$. margaritifer was released and the observations were recorded for both tagged and untagged frogs (Krebs 2014).

\section{Observation of habitat characteristics}

Observations were made on the types of plants used by $R$. margaritifer and the population data retrieval was conducted at night between 19.00-23.00 WIB using the VES method combined with line transect time search around the river flow in the heterogeneous forest area of Ranca Upas with a transect distance of $\pm 300 \mathrm{~m}$, a distance of 0-10 meters from water sources (Kusrini et al. 2007). The characteristics recorded included the type of river substrate, temperature and humidity, temperature and turbidity of the water, current velocity, $\mathrm{pH}$ of water, and plant species often used by $R$. margaritifer.

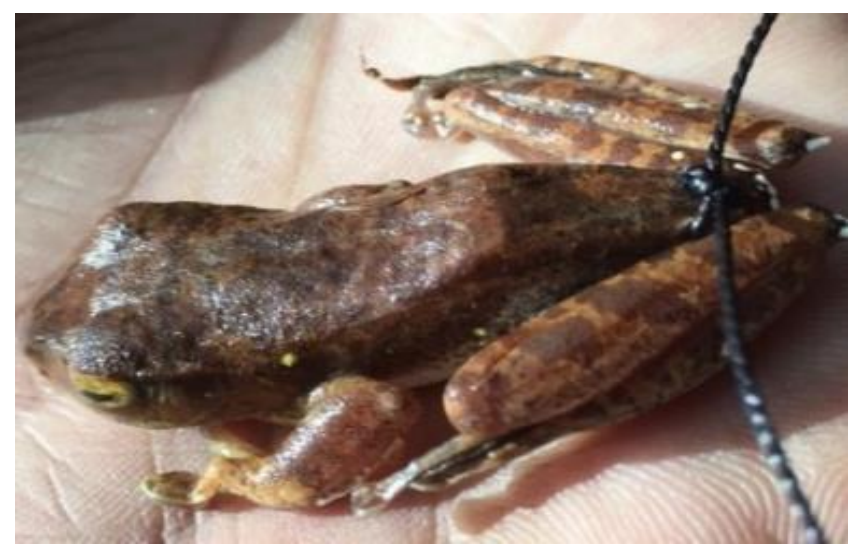

Figure 2. Shoe thread tagging of Rhacophorus margaritifer
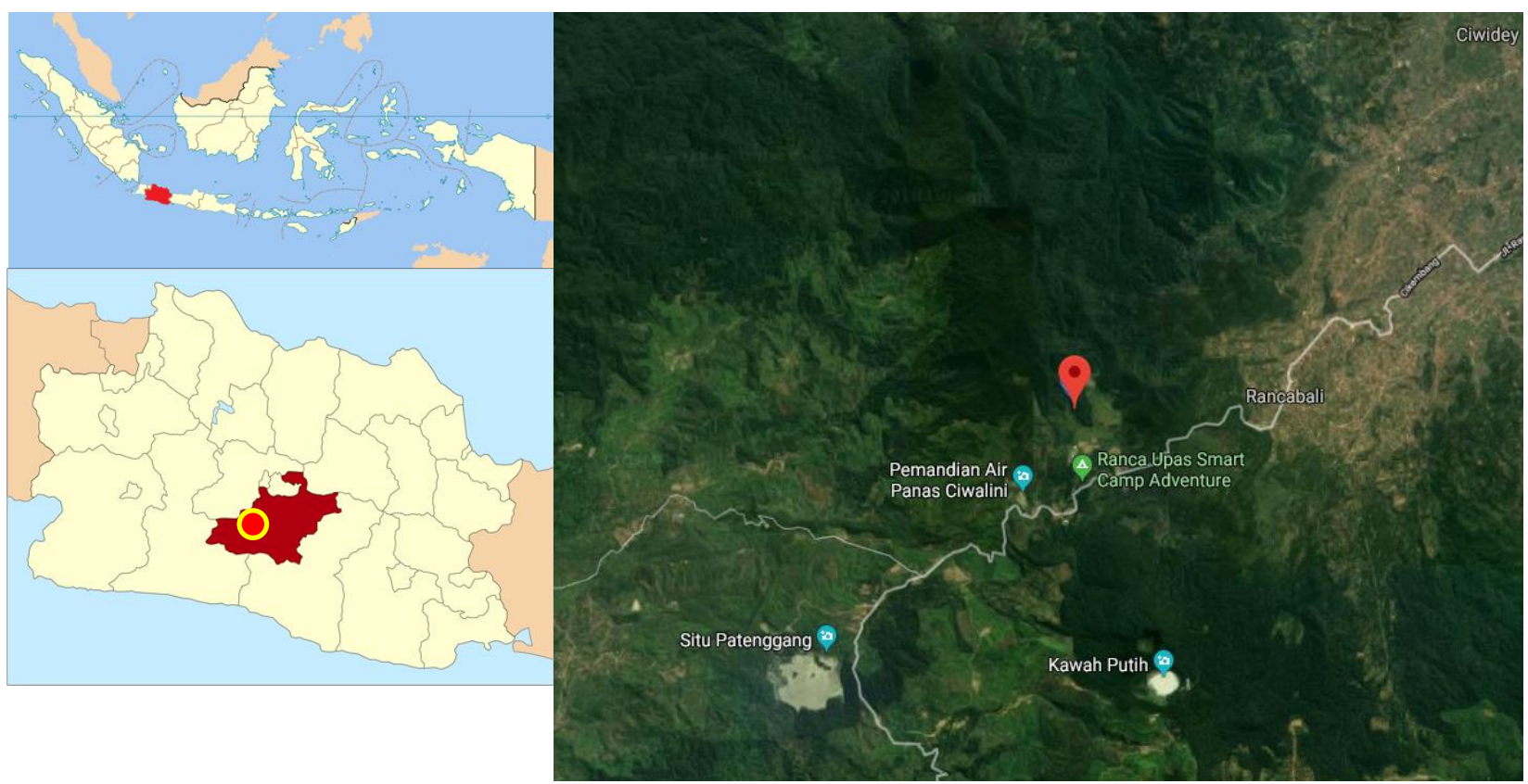

Figure 1. The map of Ranca Upas, Ciwidey, Bandung District, West Java, Indonesia 


\section{Data analysis}

Habitat characteristics

This included the percentage of frogs found in a specific plant species at the transect location and abiotic factors.

\section{Estimation of abundance}

The catching was conducted 9 times and the population abundance estimates were calculated using the Schnabel method with the following equation:

$$
\mathrm{N}=\frac{E_{\mathrm{L}}(\mathrm{Ct} \mathrm{Nt})}{\Sigma_{\mathrm{L}} \mathrm{Rt}}
$$

Where:

$\mathrm{N}=$ Estimated population abundance

$\mathrm{Ct}=$ Number of individuals caught in the sample $\mathrm{t}$

$\mathrm{Rt}=$ Number of tagged individuals in the sample $\mathrm{t}$

Mt $=$ Number of individuals tagged for the first time (released in sample t) (Krebs 2014)

Variance estimator of Schnabel can be calculated based on the inverse of $\mathrm{N}$ :

$$
\operatorname{Variance}\left(\frac{1}{\mathrm{~N}}\right)=\frac{\Sigma_{\mathrm{L}} \mathrm{Rt}}{\varepsilon_{\mathrm{L}\left[\mathrm{Ct}[\mathrm{Mt})^{2}\right.}}
$$

Standard error measurement of population density was determined by:

$$
\frac{1}{N}=\sqrt{\text { Variance } \frac{1}{N}}
$$

\section{Population density}

The population density was obtained using the following equation:

$$
\mathrm{Di}=\frac{\mathrm{ni}}{\mathrm{A}}
$$

Where:

$\mathrm{Di}=$ density type

$\mathrm{Ni}=$ Number of individuals

A $=$ Area (Krebs 2014)

\section{Population distribution}

The distribution pattern of frogs was obtained from the Morishita spread index (Morishita, 1959) as follows:

$$
\mathrm{Id}=\frac{\mathrm{ni}\left[\sum x^{2}\right]-n i}{N(N-1)}
$$

Where Id is the Morisita spread index, which is the number of plots, and $\mathrm{N}$ is the total number of individuals, $\sum X^{2}$ is the sum of squares of individual plots. The results of this deployment could be categorized into 3 criteria, which are:

Id $<1=$ The frogs are evenly distributed

Id $=1=$ The frogs are randomly spread

Id $>1=$ The frogs are spread in clumps

\section{RESULTS AND DISCUSSION}

\section{Habitat characteristics}

The research was conducted in the highlands, starting from 1630 to $1670 \mathrm{~m}$. asl. Furthermore, on a 300-meter transect, the river had a width varying from 1-2 $\mathrm{m}$ with a muddy substrate which was getting shallow as the topography was getting higher, as shown in Figure 3 and Table 1.

Rhacophorus margaritifer was found in river water flow with current velocity ranging from 0.069 to $0.079 \mathrm{~m} / \mathrm{s}$ (slow), $\mathrm{pH}$ of water 6.1-6.6, water turbidity between 4 to 8.3 NTU (Nephelometric Turbidity Unit) or it is clear enough (Ministry of Environment 2010). The recorded pH in the habitat still supports their survival. Moreover, river water quality is highly influential on the life of tadpoles of $R$. margaritifer. According to Barton and Rafinski (2006), frogsp.awn of $R$. dalmatina degenerates at a $\mathrm{pH}$ of about 4.3. Environmental factors greatly influence the life of the frogs (Dodd et al. 2010). The interaction between species and environment greatly influences their behavior as a reaction to changes in physical and biochemical factors of the environment (Tilome 2014). Amphibious habitats do not only provide the necessities of life but also the basic things needed for survival (Goin and Goin 1971). Furthermore, amphibians usually move during and after rain and are generally observed to be nocturnal (Kadadevaru and Kanamadi 2000).

Rhacophorus margaritifer lives in areas with average daily temperatures ranging between 16 and $17^{\circ} \mathrm{C}$. Aritonang (2010) suggested that this is the optimum temperature range for the eggs of $R$. margaritifer in order to avoid decay. Water temperature ranged from $14.7-15^{\circ} \mathrm{C}$ and this is considered ideal to maintain the temperature changes in amphibian body which has 70 to $80 \%$ of $r$ body weight made up of water (Hofrichter 2000). Furthermore, relative humidity ranged from $88.1-93.5 \%$ and this is observed to be quite high. The high humidity is necessary because moisture is needed to keep amphibian skin wet and to make them breathe well (Duellman and Trueb 1994). In addition, frog skin is permeable and functions as an outlet for water and air (Cogger and Zweifel 2003).

Table 1. Physical and biochemical characteristics of the river on each transect

\begin{tabular}{cccccccc}
\hline Transect & $\begin{array}{c}\text { Air temp. } \\
\left({ }^{\mathbf{0}} \mathbf{C}\right)\end{array}$ & $\begin{array}{c}\text { Humidity } \\
(\boldsymbol{\%})\end{array}$ & $\begin{array}{c}\text { Water } \\
\text { temp. }\left({ }^{\mathbf{0}} \mathbf{C}\right)\end{array}$ & $\mathbf{p H}$ & Turbidity (NTU) & $\begin{array}{c}\text { Flow speed } \\
(\mathbf{m} / \mathbf{s})\end{array}$ & Substrate \\
\hline 1 & 17.3 & 88.1 & 15.0 & 6.6 & 4.3 & 0.069 & Mud \\
2 & 16.9 & 90.8 & 14.8 & 6.3 & 4 & 0.060 & Mud \\
3 & 16.0 & 93.5 & 14.7 & 6.1 & 8.3 & 0.079 & Mud \\
\hline
\end{tabular}




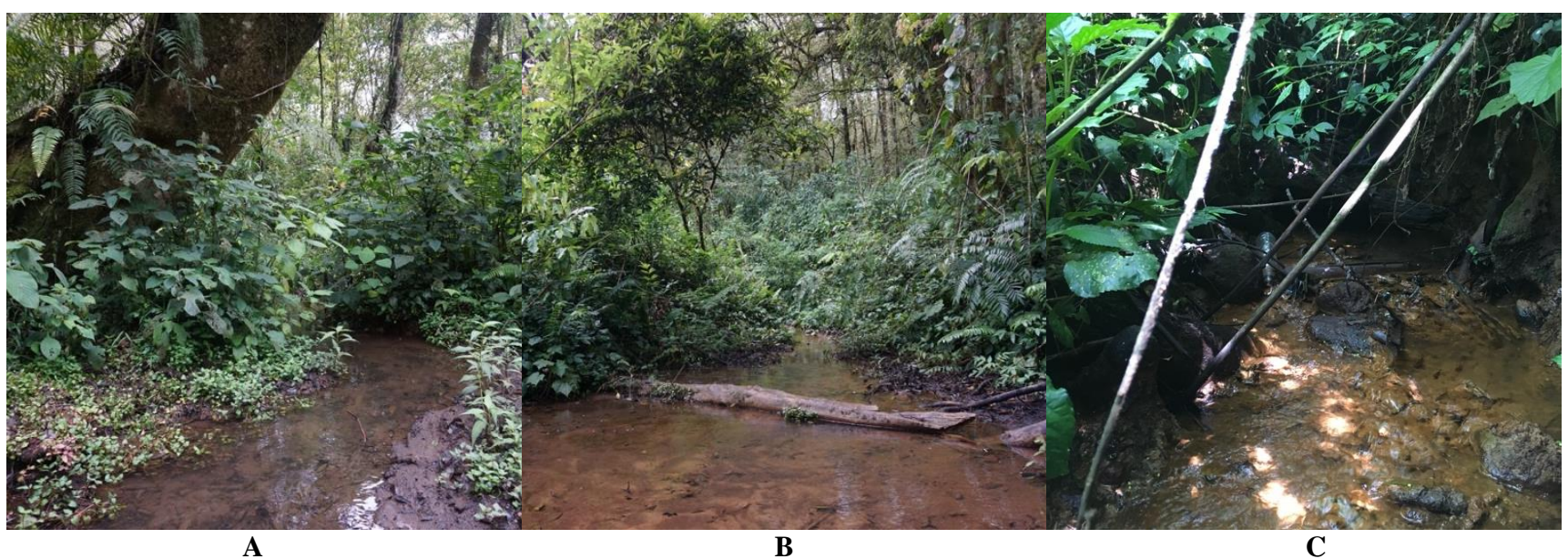

Figure 3. Habitat conditions along different points in the transect. A. Point 0-100 m, B. Point 100-200 m, C. Point 200-300 m

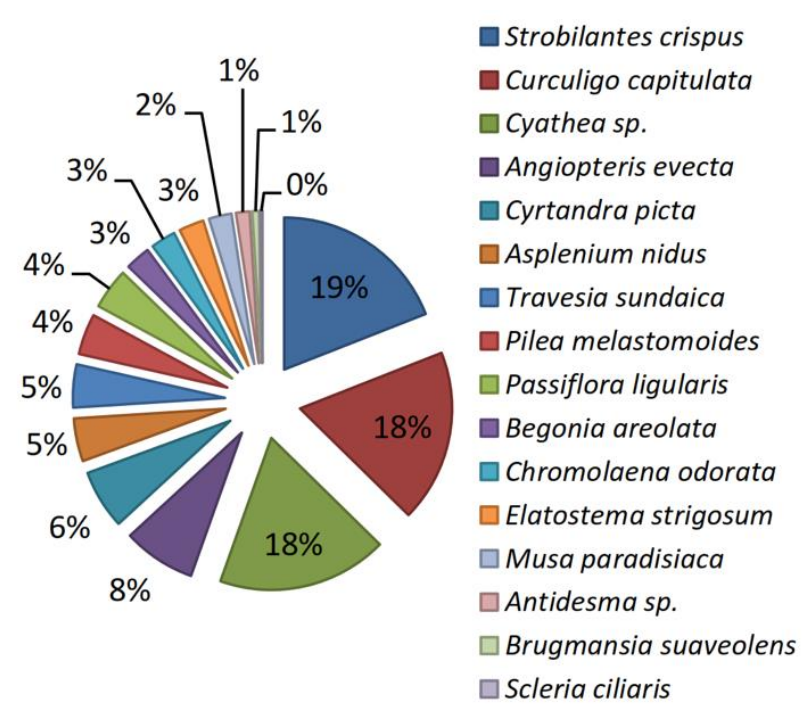

Figure 4. Percentage (\%) of Rhacophorus margaritifer occurrence on different species of plants in the heterogeneous forest areas of Ranca Upas, Ciwidey, Bandung District, West Java, Indonesia

Rhacophorus margaritifer always lives in plants near to water sources and generally explores forest canopy. Moreover, the home range is used by the species to fulfill their needs such as eating, drinking, breeding, making sound, socializing, hiding from predators, nest and rest, and to ensure its long-term sustainability (Ali et al. 2016).

The observations showed that frog starts its activities and are more often seen in open sp.aces at night, while they are mostly found under tree canopies and in leaf folds, or nodes during the day. The study showed several plants often used as habitat by this species which includes Strobilanthes crispus, Curculigo capitulata, Cyathea sp., Angiopteris evecta, Cyrtandra picta, Asplenium nidus,
Travesia sp., Passiflora ligularis, Pilea melastomoides, Chromolaena odorata, Elatostema strigosum, Begonia areolata, Musa paradisiaca, Antidesma sp., Brugmansia suaviolens, and Scleria ciliaris. The percentage of occurrence of the frog on each of these species is shown in Figure 4.

However, the most widely used plant species include Strobilanthes crispus, Curculigo capitulata, Cyathea sp. (> 18\%), Angiopteris evecta (7.71\%), Cyrtandra picta $(6.26 \%)$, and 11 others $(<5 \%)$. This result is different from that of the previous research conducted by Siregar (2013) in Gunung Gede Pangrango National Park, West Java, which showed banana/Musa paradisiaca (31-54\%) and Achasma megalocheilos (35\%) to be the most widely used habitat by $R$. margaritifer for its activities. This indicates that the species do not live in specific association with any plant, but selection of plants is more concerned with fresh leaves and closeness to water sources. Furthermore, during mating season, they would be found around water stream and will generally look for the most suitable place to place their sp.awn which is the clutch prepared by males and females on hidden leaves and hung so that the tadpoles fall directly into the water once hatched (Bain and Nguyen 2004).

During the period of this study in March 2018, we found two clutches on Strobilanthes crispus and one on the Cyathea sp. as shown in Figure 5. In the research conducted by Aritonang (2010) in Gunung Gede Pangrango National Park, $R$. margaritifer was discovered to have clutched in Brugmansia suaveolens and Eupatorium sordidum plants. Whereas in another conducted by Lestari (2013) at Taman Safari Indonesia, it was found to have clutched on Brugmansia suaveolens plants. This indicates that the frog did not have sp.ecial consideration on any type of plant but on broadleaf plants close to water sources. This was supported by the submission of Aritonang (2010) that clutch is generally placed on green leaves, hidden, and hanging on the water. 


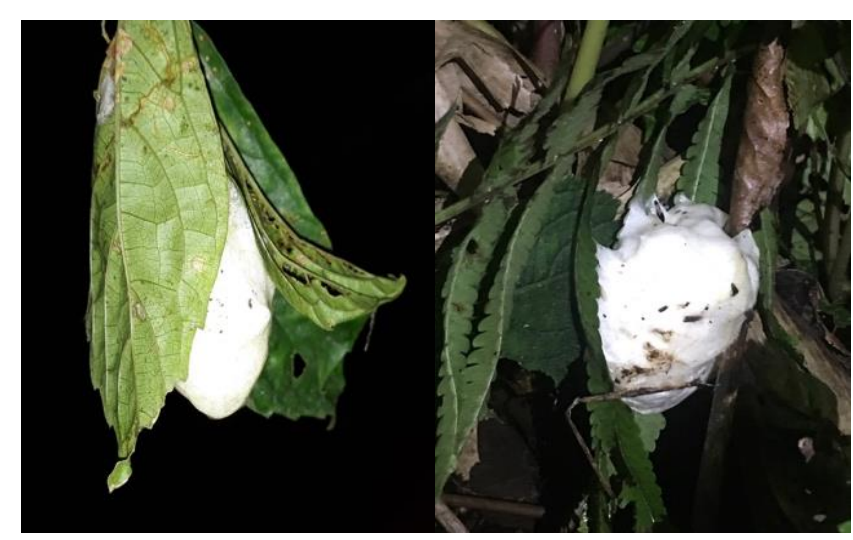

Figure 5. Clutches of Rhacophorus margaritifer hanging from plants

Table 2. Estimation of the abundance of Rhacophorus margaritifer

\begin{tabular}{llllll}
\hline $\mathbf{t}$ & $\mathbf{C t}$ & $\mathbf{R t}$ & $\mathbf{T t}$ & $\mathbf{M t}$ & $\mathbf{N}$ \\
\hline 1 & 45 & 0 & 45 & 0 & 286 \\
2 & 56 & 25 & 31 & 45 & \\
3 & 48 & 20 & 28 & 76 & \\
4 & 44 & 22 & 22 & 104 & \\
5 & 38 & 16 & 22 & 126 & \\
6 & 37 & 18 & 19 & 148 & \\
7 & 41 & 22 & 19 & 167 & \\
8 & 35 & 17 & 18 & 186 & \\
9 & 47 & 30 & 17 & 203 & \\
10 & 45 & 18 & - & 220 & \\
Total & 436 & 188 & 221 & 1.275 & \\
\hline Note: & Nut & & &
\end{tabular}

Note: t: Number of catches, N: Estimated population abundance, Ct: Number of individuals that are matched to the catch-t, Rt: Number of individuals which have been tagged in t-catch, $\mathrm{Tt}$ : Number of individuals that have not been tagged in the catch-t, Mt: Number of individuals tagged for the first time (Krebs 2014)

Table 3. The distribution pattern of Rhacophorus margaritifer based on the Morisita index

\begin{tabular}{lcc}
\hline $\begin{array}{l}\text { The heterogeneous } \\
\text { forest area of Ranca }\end{array}$ & Id & $\begin{array}{c}\text { Distribution } \\
\text { pattern }\end{array}$ \\
\cline { 2 - 3 } Upas & 1.15 & Clumped \\
\hline
\end{tabular}

Table 4. Snout to Vent Length (SVL)-size of frogs found in the heterogeneous forest area of Ranca Upas, Ciwidey Sub-district, Bandung District, West Java, Indonesia

\begin{tabular}{lc}
\hline Parameter & SVL $(\mathbf{m m})$ \\
\hline Mean & 41.1 \\
Min & 34.0 \\
Max & 65.0 \\
SD & 0.35 \\
\hline
\end{tabular}

\section{Estimation of abundance}

The abundance of the population of $R$. margaritifer in the heterogeneous forest area of Ranca Upas was found to be 286 (Table 2). It was estimated with a transect length of $\pm 300 \mathrm{~m}$ and width of 0-10 meters from the water source, using the Schnabel method. Most of them were found on the branches or leaves of plants present close to water. Kusrini et al., (2005) has reported that even in Mount Gede Pangrango National Park, Bogor, it was difficult to find these frogs $r$ away from the water source.

In the sample, the number of tagged individuals caught or recaptured on the transect was quite much while in the actual catching process, no individual from the first arrest escaped as shown in Table 2, but at the next catch, all samples were estimated to have homogeneously mixed in the population. Based on the abundance, the average density of the frog was 5 individuals $/ 100 \mathrm{~m}^{2}$. They are mostly found close to the water because it has been reported that individual $R$. margaritifer will always look for plants close to water sources (Baker et al. 2011). They are mostly found in the habitat in order to regulate their ectothermic body temperature which is dependent on external sources, such as sunlight or the surface of objects exposed to sunlight. At high temperatures, $R$. margaritifer will look for shade or water, while at low temperatures they will come out of the shade and water to dry themselves and, therefore, look for places exposed to sunlight (Cogger and Zweifel 2003).

\section{Population distribution}

The distribution pattern of $R$. margaritifer has an Id value of 1.15. The disp.ersion index value of Morisita shows that this population tends to be in clumps, as shown in Table 3. The tendency to live in a clump is due to the need of similar environmental factors and habitat conditions such as plant species, interest in approaching other individuals around, temperature and humidity, water temperature, water $\mathrm{pH}$, and distance to water sources (Michael 1994).

The distribution of the population was dominated by frogs measuring Snout to Vent Length (SVL) or body length (from head to cloaca) of $40 \mathrm{~mm}$, and the ranging was from 34 (minimum) to 65 (maximum) $\mathrm{mm}$ (Table 4). Frogs with $>50 \mathrm{~mm}$ SVL-size were very small in number which shows that the population of $R$. margaritifer in the heterogeneous forest area of Ranca Upas is dominated by young frogs. This also indicates that the forest under study is a good habitat for frogs.

\section{REFERENCES}

Ali W, Javid A, Hussain A, Bukhari SM. 2016. Diversity and habitat preferences of amphibians and reptiles in Pakistan. Pakistan Agric 48 (4): 1201-1204.

Alikodra HS. 2002. Wild Animal Management, Part 1. Forestry Faculty, Bogor Agricultural University, Bogor. [Indonesian]

Anggoro TC. 2013. Population and Habitat Characteristic of Kongkang Jeram Frog (Huia mansonii) in Yellow River Merapi National Park. [Hon. Thesis]. Gajah Mada University, Yogyakarta. [Indonesian]

Aritonang JS. 2010. The Survival of Eggs and Tadpole of Java Tree Frogs Rhacophorus margaritifer Schlegel 1837 in Gede-Pangrango National 
park West Java. [Hon. Thesis]. Bogor Agricultural University, Bogor. [Indonesian]

Artika IM, Pinontoan S, Kusrini MD. 2015. Antibacterial activity of skin secretion of bleeding toad Leptophryne cruentata and Javan tree frog Rhacophorus margaritifer. Amer J Biochem Biotechnol 11 (3): 127131.

Bain RH, Nguyen QT. 2004. Herpetofaunal diversity of Ha Giang Province in northeastern Vietnam, with descriptions of two new species. American Museum of Natural History, New York, NY.

Baker J, Beebee T, Buckley J, Gent T, Orchard D. 2011. Amphibian Habitat Management Handbook. Amphibian and Reptile Conservation, Bournemouth.

Barton K, Rafinski J. 2006. Co-occurrence of Agile Frog (Rana dalmatina Fitz. in Bonaparte) with Common Frog (Rana temporaria L.) in breeding sites in southeastern Poland. Polish J Ecol 54: 151-157

Begon M, Harper JL, Townsend CR. 1986. Ecology. Individuals, Populations and Communities. Blackwell, Oxford.

Bowne DR, Bowers MA. 2004. Interpatch movements in sp.atially structured populations: A literature review. Landscape Ecol 19 (1): 120.

Bridge CM, Semlitsch RD. 2000. Variation in pesticide tolerance of tadpoles among and within species of Ranidae and patterns of amphibian decline. Conserv Biol 14: 1490-1499.

Cogger HG, Zweifel RG. 2003. Encyclopedia of Reptiles and Amphibians. Fog City Press, San Fransisco.

Department of Forestry. 2012. Deforestation Calculation in Indonesia Period: 2009-2011. Directorate General of Forestry Planning, Forestry Department, Jakarta. [Indonesian]

Department of Tourism and Culture of West Java. 2017. Rancaupas Campground. http://www.disp.arbud.jabarprov.go.id/applications/frontend/index.

Dodd CK. 2010. Amphibian Ecology and Conservation: A Handbook of Techniques. Oxford University Press, UK.

Duellman W, Trueb L. 1994. Biology of Amphibians. The John Hopkins University Press Ltd., London.

Frost DR. 2018. Amphibian Species of the World 6.0, an Online Reference. www.research.amnh.org

Gibbs JP. 1998a. Amphibian movements in resp.onse to forest edges, roads, and streambeds in southern New England. J Wildl Manag 62: 584-589.

Goin CJ, Goin OB. 1971. Introduction to Herpetology. Second Edition. Freeman, San Francisco

Hero J. 1989. A simple code for toe clipping anurans. Herpetol Rev 20 (3): 66-67.

Hofrichter. 2000. The Encyclopedia of Amphibians. Weltbild Verlag $\mathrm{GmbH}$, Augsburg

Iskandar DT. 1998. Amphibia of Java and Bali-Series of Field Guide. Puslitbang LIPI, Bogor. [Indonesian]

IUCN. 2009. IUCN Red List of Threatened Species. www.iucnredlist.org.

IUCN. 2013. Endemic Indonesia. www.iucnredlist.org.

Kadadevaru GG, Kanamadi RD. 2000. Courtship and nesting behavior of the Malabar Gliding Frog, Rhacophorus malabaricus (Jerdon, 1870). Curr Sci 79 (3): 377-380.

Kurniati H. 2003. Amphibians and Reptiles of Gunung Halimun National Park. West Java, Indonesia. Research Center for Biology, LIPI, Cibinong, Bogor.
Kusrini MD, Yazid M, Ul-Hasanah AU, Hamidy A. 2007. Preliminary study on the distribution and biology of the bleeding toad, Leptophryne cruentata Tschudi, 1838. In: Kusrini MD (ed.). Frogs of Gede Pangrango: A follow up project for the conservation of frogs in West Java, Indonesia. Book 1: Main report. Technical report submitted to the BP Conservation Programme. Bogor Agricultural University, Bogor. [Indonesian]

Kusrini MD. 2013. Identification of West Java Amphibia. Forest Faculty, Bogor Agricultural University and Directorate of Biodiversity Conservation, Bogor. [Indonesian]

Krebs CJ. 2014. Ecological Methodology. 3rd ed. Benjamin Cummings, Menlo Park, CA.

Lestari AE. 2013. Adaptation and Behaviour of Javan Tree Frog (Rhacophorus Margaritifer Schlegel 1837) in Indonesia Safari Park, Cisarua, West Java. [Hon. Thesis]. Bogor Agricultural University, Bogor. [Indonesian]

Lubis MI. 2008. Javan Tree Frog Habitat Sp.atial Modeling (Rhacophorus javanus, Boettger 1893) Using Geographic Information Systems and Remote Sensing in Gede Pangrango National Park, West Java, Bogor. [Hon. Thesis]. Bogor Agricultural University, Bogor. [Indonesian]

Ministry of Environment. 2010. Management of Water Pollution Control. A copy of the Regulation of the Minister of Environment No. 01 of 2010. [Indonesian]

Michael PE. 1994. Ecology Methods for Farm and Laboratory Research. Indonesia University, Jakarta. [Indonesian]

Mittermeier RA, Robles GP, Mittermeier CG. 1997. Megadiversity. CEMEX, Mexico City, Mexico.

Morishita. 1959. Measuring of the disp.ersion of individuals and analysis of the distributional patterns. Memoir of the Faculty of Science, Series E2, Kyushu University, Japan.

Indonesia Government Regulation. 2015. Revision of Government Regulation No. 28 of 2011 about Natural Reserve and Conservation Area Management. [Indonesian]

Semlitsch RD. 2000. Principles for management of aquatic-breeding amphibians. J. Wildl. Manag 64: 615-631.

Schnabel ZE. 1938. The estimation of the total fish population of a lake. Amer Math Monthl 45: 348-352.

Siregar BA. 2013. Pattern of Daily Moving of Javan Tree Frog (Rhacophorus margaritifer) Using Radio Tracking Method in Gede Pangrango National Park, Jawa Barat. [Hon. Thesis]. Bogor Agricultural University, Bogor. [Indonesian]

Soegianto A. 1994. Ecology Quantitative. Usaha Nasional Press, Surabaya. [Indonesian]

Stebbins C. 1997. A Natural History of Amphibians. Princeton University Press, NJ.

Stuart SN, Chanson JS, Cox NA, Young BE, Rodrigues ASL, Fischman DL, Waller RW. 2004. Status and trends of amphibian declines and extinctions worldwide. Science 306: 1783-1786.

Tilome IT. 2014. Microhabitat and Density of Grasshopper Population in Corn Field (Zea mays). [Hon. Thesis]. State University of Gorontalo, Gorontalo. [Indonesian]

van Kampen PN. 1923. The Amphibia of the Indo-Australian Archipelago. Library of The American Museum of Natural History. E. J. Brill Ltd., Leiden. 